[Radiocarbon, Vol. 13, No. 1, 1971, P. 26-28]

\title{
INSTITUTE OF GEOLOGICAL SCIENCES RADIOCARBON DATES I
}

E. WELIN, L. ENGSTRAND, and S. VACZY

Radioactive Dating Laboratory, Stockholm, Sweden*

This date list was compiled by the Institute of Geological Sciences (U.K.) incorporating data supplied under contract by Dr. E. Welin, Radioactive Dating Laboratory, Stockholm. Unless otherwise stated age figures are in $\mathrm{C}^{14}$ years before A.D. 1950. The half-life of $\mathrm{C}^{14}$ is taken as 5568 years and the standard error is given as a standard deviation of $1 \sigma$. Correction for $\mathrm{C}^{13} / \mathrm{C}^{12}$ has not been made. This is the first of a series of annotated lists of $\mathrm{C}^{14}$ dates of British and overseas material in course of preparation by the Institute. \section{B.c.}

Peat from borehole at St. Michael's Wood, $\left(56^{\circ} 24^{\prime} \mathrm{N}\right.$ Lat, $2^{\circ} 53^{\prime}$ W Long, Grid Ref. NO 4541 2348) in peat bog at landward limit of postGlacial raised beach. Depth below surface 1.00 to $1.15 \mathrm{~m}$; overlies wedge of clastic deposits marking limit of Flandrian transgression. Coll. 1969 and subm. by J. I. Chisholm, Inst. of Geol. Sciences.

\section{IGS-C14/2. (St 3063) Leuchars, Fife \\ $7605 \pm 130$}

Peat from same borehole as IGS C14/1, at depth 2.35 to $2.50 \mathrm{~m}$ below surface. Underlies wedge of clastic deposits marking limit of Flandrian transgression. Coll. 1969 and subm. by J. I. Chisholm.

\section{IGS-C14/3. (St 3064) Leuchars, Fife}

Peat from same borehole as IGS C14/1 at depth 3.75 to $3.90 \mathrm{~m}$ below surface, at base of peat sequence, resting on late-Glacial sand. Coll. 1969 and subm. by J. I. Chisholm.

\section{IGS-C14/4. (St 3057) Leeds, Yorkshire}

$4280 \pm 100$ 2330 B.c.

Wood fragment from 'upper sand and gravel' at Oxbow Opencast Coal site (53 $46^{\prime} \mathrm{N}$ Lat, $1^{\circ} 28^{\prime} \mathrm{W}$ Long, Grid Ref. SE 361 300), in Aire Valley. Coll. 1964 and subm. by G. D. Gaunt, Inst. of Geol. Sciences. Comment: sample was derived from an horizon containing abundant horizontally disposed tree trunks. Pollen analyses by J. W. Franks, Univ. of Manchester, of silts and clays below and above this horizon suggest correlations with Flandrian Zones VI and VIIb, respectively (Gaunt, Coope, and Franks, in press). Age determination is compatible with these correlations. Pollen of Cerealia and Plantaginaceae was present in the silts and clays above the tree trunks. Abundance of trees at this horizon may possibly reflect forest clearance.

* Published by permission of the Director, Institute of Geological Sciences, Exhibition Road, London S.W.7. The Institute is a contracting agency, not a dating laboratory, yet IGS at London is the "author" when needed for interlaboratory communications. 
IGS-C14/5. (St 3071 A, outer fraction)

$5535 \pm 160$

Aberlady, East Lothian

3585 B.C.

(St $3071 \mathrm{~B}$, inner fraction)

$5070 \pm 180$

Aberlady, East Lothian

3120 B.C.

Shells from temporary sec. $\left(56^{\circ} 1^{\prime} \mathrm{N}\right.$ Lat, $2^{\circ} 51^{\prime} \mathrm{W}$ Long, Grid Ref. NT 4713 8053) from a fossil life assemblage of Ostrea edulis Linn. and Mya truncata Linn., respectively, lying on, or burrowed into a platform of till $1.8 \mathrm{~m}$ above O.D. Covered by $1 \mathrm{~m}$ of estuarine chacial raised beach little below low water mark. Correlated with a po. D. McAdam, Inst. of $8.55 \mathrm{~m}$ above O.D. Coll. 1968 and subam and Shelagh M. Smith).

Geol. Sciences. (Descr. by A. D. McAdam and $2505 \pm 100$

IGS-C14/6. (St 3065) Aberlady, East Lothian 555 B.c.

Peat from temporary sec. at Luffness Links $\left(56^{\circ} 1^{\prime} \mathrm{N}\right.$ Lat, $2^{\circ} 51^{\prime}$ Peat from temporary sec. at Luffness Linge
W Long, Grid. Ref. NT 47108130 ) in peat wedge underlying $1 \mathrm{~m}$ sand,
overlying estuarine clay. Probably lies near former high water mark at
6 $6 \mathrm{~m}$ above O.D. Coll. 1968 and subm. by A. D. McAdam.

IGS-C14/7. (St 3070) Loch Linnhe area, Argyll

Shells from semi-consolidated plastic clay excavated around screw of sunken ship $\left(56^{\circ} 29^{\prime} \mathrm{N}\right.$ Lat, $5^{\circ} 25^{\prime} \mathrm{W}$ Long). Sample $6 \mathrm{ft}$ below sea floor, probably never above sea level since its formation. Level ca. $100 \mathrm{ft}$ below O.D. Coll. and subm. by R. A. Eden. (Note by D. C. Greig).

IGS-C14/8. (St 3066) Belfast

$9130 \pm 120$

Peat from borehole in Castle Arcade ( $54^{\circ} 36^{\prime} \mathrm{N}$ Lat, $5^{\circ} 56^{\prime} \mathrm{W}$ Long, Grid Ref. J 3390 7425). Depth $14.94 \mathrm{~m}$ below surface; from layer of peat at base of estuarine clay. Coll. 1968 and subm. by H. E. Wilson, peat at base of estuarine clay. Coll. in Belfast Lough, Stephens (1968)
Inst. of Geol. Sciences. Comment:
assigned peat beneath the estuarine clay to Zone VI C, dating to ca. 8200 B.P. New datings place the basal peat at V/VI transition and indicate a much earlier date than has hitherto been suspected. Alternatively, peat deposition in the Belfast area may have been a polyphase event.

IGS-C14/9. (St 3058) Belfast

$8715 \pm 100$

Wood from same borehole at depth $11.59 \mathrm{~m}$ below surface in estuarine clay. Coll. 1968 and subm. by H. E. Wilson. Comment: same as for IGS-C14/8.

IGS-C14/10. (St 3067) Birmingham

Plant remains washed from peat bed in core sample between 6.81 $\mathrm{m}$ and $6.88 \mathrm{~m}$ depth from Quinton No. 1 Borehole $\left(52^{\circ} 28^{\prime} \mathrm{N}\right.$ Lat, $2^{\circ} 00^{\prime}$ W Long, Grid Ref. SO 9921 8471). Peat from part of sequence of organic sediments sandwiched between glacial deposits. Coll. 1969 and 

subm. by A. Horton, Inst. of Geol. Sciences. Contained insect fauna
and plant remains indicate interglacial age.

IGS-C14/11

Wood fragment 3059) West Bromwich

$12,165 \pm 160$

10,215 в.C.

of small tributary of R. $N$ Lat, $1^{\circ} 58^{\prime} \mathrm{W}$ Long, Grid Ref $\mathrm{SP} 0213$ upon glacial gravels $\left(52^{\circ} 32^{\prime}\right.$ by A. Horton.

\section{IGS-C14/12.}

(St 3060) West Bromwich

$9970 \pm 110$

8020 B.c.

described above. Coll. and subm. by A. Horton. $0.61 \mathrm{~m}$ above base of peat

\section{IGS-C14/13. (St 3068) Wittersham, Kent $\quad 3560 \pm 100$}

Peat from depth $4.27 \mathrm{~m}$ below surface Kent $\mathbf{1 6 1 0}$ B.c.

$0^{\circ} 41^{\prime} \mathrm{E}$ Long, Grid Ref. TQ 885258$)$ at $\mathrm{B}$. Rother Valley. Drift deposits, $31.4 \mathrm{~m}$ thi) at Blackwall Bridge in the 3.66 to $6.7 \mathrm{~m}$ below surface. Pollen thick, included a bed of peat from of peat at $3.81 \mathrm{~m}$ yielded a pollen analysis made by Charles Turner and at $6.25 \mathrm{~m}$ a spectrum suggesting Zoctrum referable to Zone VII $b$, 1968 and subm. by E. R. Shephard-Thore VII a (pre-elm decline). Coll. ment: dates agree with palynologic evi, Inst. of Geol. Sciences. Comdates from the older near-surface peats of $\mathrm{Ron}$ and also with previous (see below) is one of the oldest peats of Romney Marsh. IGS-C14/14 peat may have started to accumulate so far obtained and suggests that prior to its general accumulation in Romnis part of the Rother Valley

\section{IGS-C14/14. (St 3069) Wittersham, Kent $\quad 4845 \pm 100$}

Peat from same borehole at depth, Kent 595 B.c.

Coll. 1968 and subm. by E. R. Shephard 5.89 to $5.97 \mathrm{~m}$ below surface. 13.

\section{IGS.C14/15. (St 3061) Arlington, Sussex $\quad 9435 \pm 120$}

nel of R. Cuckmere at perty layer forming floor to the buried chan subm. by R. D. Lake, Inst of (25 ft below surface). Coll. 1969 and sec. of Arlington Reservoir dam $\left(50^{\circ}\right.$ Sciences, from excavations for $\mathrm{E}$ Ref. TQ 538 074).

Gaunt, G. D., Coope, References

cast Coal site in the Aire Valley, Yorkshire: Yuaternary deposits at Oxbow Open

Stephens, Nicholas, 1968, Late Glacial andire: Yorks. Geol. Soc. Proc., in press. Internatl. Assoc. for Quaternary Research 8, Proc. VII, p. $437-456$.
Successions Congress, 